\title{
MENINGKATKAN PRESTASI BELAJAR INSTALASI PENERANGAN LISTRIK MENGGUNAKAN PROBLEM BASED LEARNING
}

\author{
MUHAIMIN \\ SMK Negeri 1 Bangil Pasuruan \\ Email : muhaimin.pogar@gmail.com
}

\begin{abstract}
ABSTRAK
Tujuan dari penelitian ini adalah untuk meningkatkan prestasi belajar Instalasi Penerangan Listrik dengan menggunakan model pembelajaran PBL (Promblem Based Learning) pada siswa kelas XI Listrik SMK Negeri 1 Bangil Kabupaten Pasuruan tahun pelajaran 2018/2019. Penelitian ini dilakukan karena rendahnya rata-rata nilai prestasi belajar Instalasi Penerangan Listrik siswa kelas XI Listrik di SMK Negeri 1 Bangil kabupaten Pasuruan. Penelitian ini merupakan penelitian tindakan kelas yang terdiri dari dua siklus, dalam satu siklus terdapat empat tahapan yaitu perencanaan (planning), pelaksanaan/tindakan (action), pengamatan (observation), dan refleksi (reflection). Penggunaan model pembelajaran PBL (Promblem Based Learning) dimaksudkan dapat meningkatkan motivasi belajar Instalasi Penerangan Listrik agar dapat mencapai tujuan pembelajaran yang diinginkan. Setelah diadakan proses pembelajaran menggunakan model Promblem Based Learning dan diakhiri dengan evaluasi melalui tes tertulis diperoleh data yaitu pada siklus I, nilai rata-rata kelas 65,77 dan dari 39 siswa terdapat 23 siswa $(58,97 \%)$ sudah mencapai nilai ketuntasan yaitu $\geq 70$, pada siklus II hasil evaluasi diperoleh rata-rata kelas 72,46 dan dari 39 siswa terdapat 30 siswa $(76,92 \%)$ sudah mencapai nilai ketuntasan $\geq 70$ dan pada siklus III hasil evaluasi diperoleh rata-rata kelas 78,90 dan dari 39 siswa terdapat 34 siswa $(87,18$ $\%$ ) . Dengan demikian penggunaan model pembelajaran PBL (Promblem Based Learning) dapat meningkatkan prestasi belajar Instalasi Penerangan Listrik.
\end{abstract}

Kata Kunci : Prestasi Belajar, Instalasi Penerangan Listrik, PBL

\section{PENDAHULUAN}

Dunia Pendidikan Indonesia tengah berupaya melakukan perbaikan kondisi pembelajaran diseluruh jenjang pendidikan dengan meluncurkan kurikulum berbasis kompetensi (KBK) yang masih uji coba. Hal ini merupakan salah satu perwujudan upaya mengimplementasikan paradigma baru dalam dunia pendidikan yang diharapakan Student Centered yaitu berpusat pada siswa. Pembelajaran di sekolah diharapkan dilakukan berdasarkan filosofi kontruktivisme yaitu memberi kesempatan kepada siswa untuk "membangun" sendiri pemahamannya melalui pengalaman belajar dengan memanfaatkan pengetahuan awal yang telah dimiliki.

Berdasarkan hasil observasi yang telah dilakukan di kelas XI Listrik SMK Negeri 1 Bangil tahun pelajaran 2018/2019, ternyata proses pembelajaran masih bersifat tradisional dalam arti guru menyampaikan materi pelajaran hanya dengan berceramah (Teacher Centered) sehingga peran guru sangat dominan dan siswa tidak pernah terlibat langsung di dalam proses pembelajaran. Kenyataan di lapangan tersebut menjadi suatu permasalahan karena bertentangan dengan karakteristik dalam kurikulum berbasis kompetensi, dimana proses pembelajaran berpusat pada siswa (Student Centered) tidak berpusat pada guru (Teacher Centered) sehingga fungsi guru bukan sebagai pusat informasi melainkan sebagai fasilitator dalam pembelajaran.

Dengan adanya perubahan kurikulum yang berorientasi pada kompetensi dan untuk mengatasi permasalahan di atas mengharuskan kesadaran guna untuk mengubah cara pembelajaran tradisional menjadi model pembelajaran yang inovatif. Salah satu model pembelajaran yang mungkin dapat mengatasi keadaan tersebut adalah model pembelajaran kooperatif. Untuk mendukung model pembelajaran kooperatif dan konsep yang diajarkan lebih bermakna bagi siswa diperlukan suatu pendekatan. Salah satu pendekatan yang mungkin dapat diterapkan di kelas 
tersebut adalah pendekatan PBL (Problem Based Learning) karena dalam pendekatan tersebut dapat membantu guru untuk mengaitkan antara konsep yang diajarkan dengan situasi dunia nyata sehingga siswa dapat belajar berdasarkan pengalaman dari lingkungan di sekitarnya. Perolehan pengalaman dari lingkungan sekitar bisa diperoleh dari interaksi dengan orang lain dalam arti siswasaling bekerja sama dalam suatu kelompok. Sehingga ada kesesuaian antara model pembelajaran kooperatif dengan pendekatan pembelajaran berdasarkan masalah tersebut. Berdasarkan uraian tersebut di atas peneliti memandang perlu melakukan suatu penelitian tindakan (action research) untuk mengatasi masalah yang ada yaitu meningkatkan prestasi belajar Instalasi Penerangan Listrik melalui PBL (Problem Based Learning) pada siswa kelas XI Listrik SMK Negeri 1 Bangil Tahun Pelajaran 2018/2019.

Tujuan yang ingin dicapai dalam penggunaan model pembelajaran PBL (Problem Based Learning) adalah menumbuhkan kemampuan siswa untuk berpikir kreatif, analitis, sistematis, dan logis untuk menemukan alternatif pemecahan masalah malalui eksplorasi data secara empiris dalam rangka menumbuhkan sikap ilmiah sehingga tujuan dari tindakan kelas yang diinginkan dapat tercapai yaitu meningkatkan prestasi belajar Instalasi Penerangan Listrik.

Kelebihan dalam penerapan model pembelajaran Problem Based Learning (PBL), yaitu pemecahan masalah merupakan teknik yang cukup bagus untuk lebih memahami isi pelajaran sehingga pembelajaran lebih bermakna, menantang kemampuan siswa dan memberikan kepuasan untuk menemukan pengetahuan baru bagi siswa, dapat meningkatkan aktivitas pembelajaran siswa, dan dapat membantu siswa bagaimana mentransfer pengetahuan siswa untuk memahami masalah dalam kehidupan nyata.

\section{METODE PENELITIAN}

Proses dan hasil belajar Instalasi Penerangan Listrik merupakan bahan untuk menyusun RPP (Rencana Pelaksanaan Pembelajaran) dan PTK (Penelitian Tindakan Kelas). Dalam hal ini sebagai peneliti, guru harus menetapkan materi dan model pembelajaran yang cocok agar kualitas pembelajaran lebih baik. Penelitian ini merupakan Penelitian Tindakan Kelas dengan tiga siklus. Tempat penelitian di SMK Negeri 1 Bangil Kabupaten Pasuruan. Waktu penelitian ini dilakukan pada bulan Februari sampai dengan Mei 2019. Mata pelajaran yang menjadi sasaran penelitian ini adalah Instalasi Penerangan Listrik kelas XI. Sasaran dalam penelitian ini adalah siswa kelas XI Listrik 1 SMK Negeri 1 Bangil kabupaten Pasuruan Tahun Pelajaran 2018/2019 yang berjumlah 39 siswa.

Penelitian Tindakan Kelas adalah suatu bentuk kajian yang bersifat sistematis reflektif oleh pelaku tindakan untuk memperbaiki kondisi pembelajaran yang dilakukan. Adapun tujuan utama dari penelitian tindakan kelas ini adalah memperbaiki/meningkatkan pratik pembelajaran secara berkesinambungan, sedangkan tujuan penyertaannya adalah menumbuhkan budaya meneliti di kalangan guru (Mukhlis, 2000: 5).

Sesuai dengan jenis penelitian yang dipilih, yaitu penelitian tindakan kelas, maka penelitian ini menggunakan model penelitian tindakan dari Kemmis dan Taggart dalam Arikunto (2007: 97), yaitu berbentuk spiral dari siklus yang satu ke siklus yang berikutnya. Setiap siklus meliputi planning (rencana), action (tindakan), observation (pengamatan), dan reflection (refleksi). Langkah pada siklus berikutnya adalah perncanaan yang sudah direvisi, tindakan, pengamatan, dan refleksi. Sebelum masuk pada siklus 1 dilakukan tindakan pendahuluan yang berupa identifikasi permasalahan. Siklus spiral dari tahap-tahap penelitian tindakan kelas dapat dilihat pada gambar 1 berikut : 


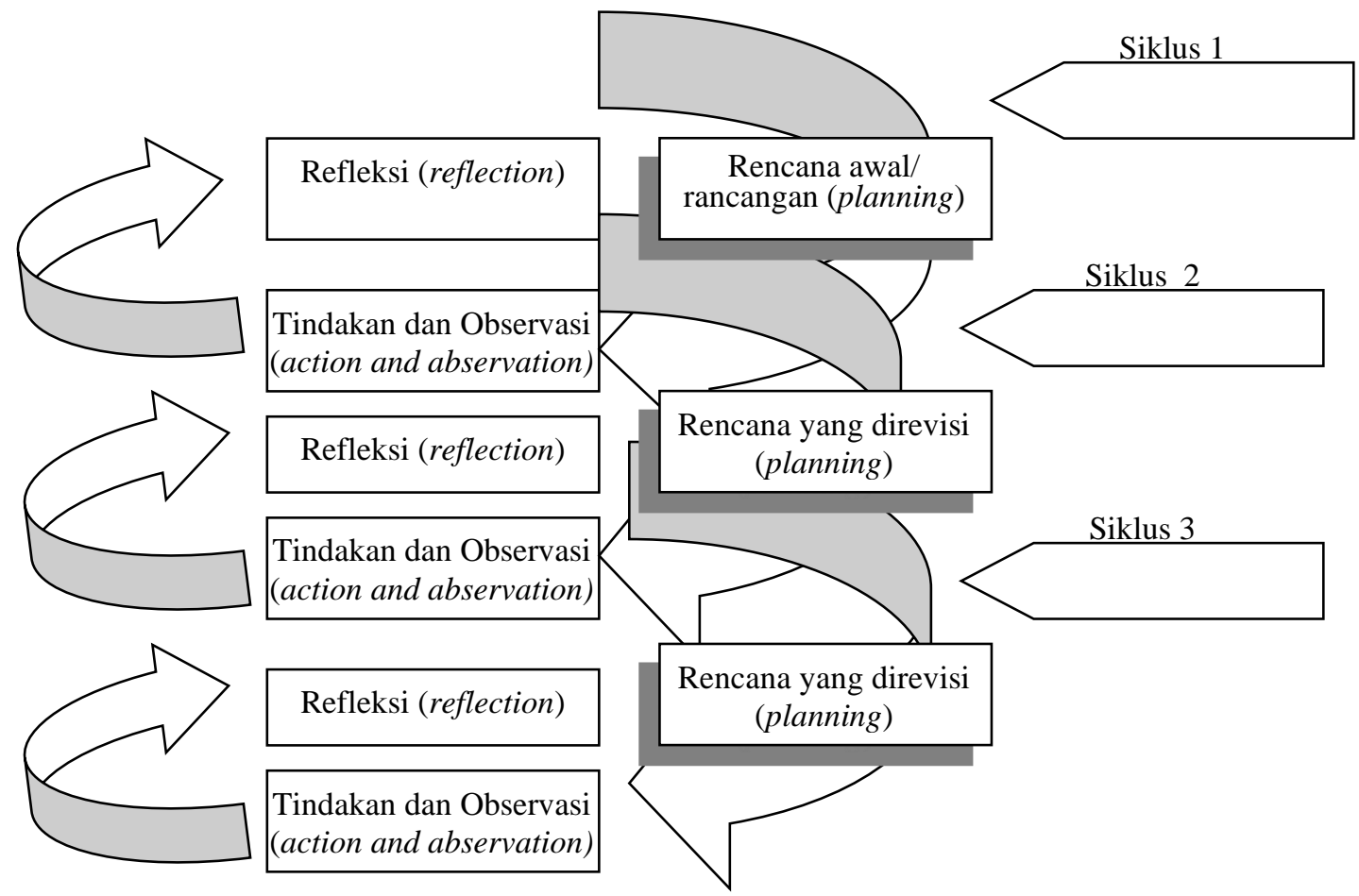

Gambar 1. Alur Penelitian Tindakan Kelas

Alur penelitian tindakan kelas menurut Kemmis dan Taggart yang berbentuk spiral dari siklus yang satu ke siklus yang berikutnya adalah: (1) Rancangan/rencana awal (planning) sebelum mengadakan penelitian, peneliti menyusun rumusan masalah, tujuan dan membuat rencana tindakan, termasuk di dalamnya instrumen penelitian dan perangkat pembelajaran, (2) Kegiatan dan pengamatan (action and abservation) meliputi tindakan yang dilakukan oleh peneliti yaitu penerapan model pembelajaran PBL (Problem Based Learning), (3) Refleksi (reflection), peneliti mengkaji, melihat dan mempertimbangkan hasil atau dampak dari tindakan yang dilakukan berdasarkan hasil evaluasi/tes yang diperoleh siswa, dan (4) Rancangan/rencana yang direvisi (planning), berdasarkan hasil refleksi yang diperoleh dari tindakan (siklus) yang berlangsung untuk dilaksanakan pada siklus berikutnya.

Pada tahap refleksi diperoleh data hasil tes siswa yang dilakukan diakhir pembelajaran pada tiap siklus, dan hasilnya diperoleh sebagai berikut: (1) Jika siklus 1 sudah memenuhi kriteria ketuntasan kelas yaitu $\geq 80 \%$ mencapai nilai $\geq 70$ maka siklus 2 tidak perlu dilaksanakan dan jika siklus 1 belum memenuhi kriteria ketuntasan maka perlu diadakan siklus 2, (2) Jika siklus 2 sudah memenuhi kriteria ketuntasan kelas yaitu $\geq 80 \%$ mencapai nilai $\geq 70$ maka siklus 3 tidak perlu dilaksanakan dan jika siklus 2 belum memenuhi kriteria ketuntasan maka perlu diadakan siklus 3 dan seterusnya, dan (3) Dalam setiap siklus dikenai perlakuan yang sama (alur kegiatan yang sama) dan membahas satu sub pokok bahasan yang diakhiri dengan tes formatif di akhir masing siklus.

Instrumen yang digunakan dalam penelitian ini adalah Tes Formatif. Tes ini disusun berdasarkan tujuan pembelajaran yang akan dicapai dan digunakan untuk menghitung kemampuan pemahaman siswa terhadap pembelajaran Instalasi Penerangan Listrik. Tes formatif ini diberikan pada setiap akhir siklus dalam bentuk soal obyektif. Untuk menganalisis tingkat keberhasilan atau presentase keberhasilan siswa setelah proses belajar mengajar setiap siklus dilakukan dengan cara memberikan evaluasi berupa soal tertulis pada setiap akhir siklus. Analisis ini dihitung dengan menggunakan statistik sederhana yaitu: (1) Menghitung persentase Hasil Belajar siswa (daya serap) persiklus dengan menggunakan rumus : 


$$
\text { Persentase }(\%)=\frac{\text { Jumlah jawab benar }}{\text { Nilai maksimum }} \times 100 \%
$$

dan (2) Menghitung persentase ketuntasan kelas dengan menggunakan rumus :

$$
\text { Ketuntasan Kelas }=\frac{\text { jumlah. siswa yang tuntas belajar }}{\text { jumlah siswa }} \times 100 \%
$$

Siswa secara berkelompok atau satu kelas dianggap tuntas belajar bila ketuntasan kelas mencapai $\geq 80 \%$ dari jumlah siswa yang mencapai daya serap $\geq 70$ (kriteria baik)

\section{HASIL DAN PEMBAHASAN}

Input yang berasal dari tahapan evaluasi (evaluation) akan sangat berguna untuk tahapan analisis (analysis) pada pengembangan berikutnya (Nancy Angko, 2013: 10). Dalam penelitian ini, tahapan analisis dilakukan berdasarkan tahapan evaluasi dari pengembangan yang sebelumnya. Hasil evaluasi yang dilakukan terhadap 39 siswa dengan metode pembelajaran yang konvensional belum dapat meningkat motivasi dan prestasi belajar Instalasi Penerangan Listrik, sehingga berdampak pada rendahnya nilai yang diperoleh siswa. Hal ini dibuktikan dengan nilai rata-rata siswa 56,24. Nilai tersebut jauh dibawah nilai KKM (Kriteria Ketuntasan Minimal), yaitu 70, dan dari 39 siswa terdapat 6 siswa $(15,38 \%)$ yang memperoleh nilai ketuntasan kelas yang itu meperoleh nilai $\geq 70$ sedangkan 33 siswa $(84,62 \%)$ memperoleh nilai dibawah KKM yaitu memperoleh nilai < 70. Dengan demikian, kriteria ketuntasan belum memenuhi indikator pencapaian.

Selanjutnya peneliti melakukan penelitian tindakan kelas siklus I, yaitu dengan diterapkannya metode pembelajaran dengan menggunakan PBL (Problem Based Learning) dengan langkah-langkah sebagai berikut : (1) Pembelajaran dilaksanakan dalam kelompok-kelompok kooperatif yang terdiri dari 4-5 orang tiap kelompok dan bersifat heterogen. Artinya tiap kelompok harus ada laki-laki dan perempuan, berkemampuan tinggi dan berkemampuan rendah. Pembentukan kelompok tersebut sudah dilaksanakan sehari sebelum proses belajar mangajar dimulai, (2) Mendiskusikan menguasai jenis peralatan dan standarisasi gambar teknik, (3) Kemudian guru meminta siswa melakukan kegiatan yang ada di LKS yang telah diberikan secara berkelompok dan guru mengamati aktivitas siswa secara bergantian, serta membimbing siswa ketika ada kesulitan. Pada saat identifikasi/penemuan masalah tidak semua anggota kelompok ikut bekerja walaupun semua berada dalam kelompok tersebut. Sebagian besar kelompok sangat bergantung pada bantuan guru dalam melakukan identifikasi masalah disekitar dan kegiatan ini memakan waktu yang cukup lama tetapi siswa bersungguh-sungguh dalam melakukan identifikasi masalah, (4) Pembelajaran dilanjutkan dengan presentasi hasil kegiatan guru meminta salah satu kelompok untuk mempresentasikan dari apa yang telah dikerjakan di depan kelas untuk diadakan diskusi, serta membahas hasil kegiatan sesuai dengan LKS dan kelompok lainnya memberikan tanggapan. Dalam proses ini presentasi kelompok sudah sesuai dengan permasalahan yang dibahas tetapi waktunya cukup singkat. Jawaban atau tanggapan pertanyaan dari masing-masing kelompok bermacam-macam membuat suasana diskusi menarik tetapi terkesan ramai dan guru terpaksa mendominasi proses jalannya diskusi karena waktu yang tersisa tidak memungkinkan bila diskusi dibiarkan sepenuhnya seperti yang diharapkan.

Pada akhir pembelajaran disampaikan kesimpulan proses pembelajaran pada hari ini dan peneliti/guru menyampaikan bahwa pada pertemuan berikutnya diadakan tes tertulis secara individu. Tes dilakukan untuk mengetahui sejauh mana keberhasilan siswa dalam pembelajaran Instalasi Penerangan Listrik dengan menggunakan model pembelajaran PBL (Problem Based Learning). Pada kegiatan ini ditemukan bahwa prestasi belajar dalam kegiatan siklus I ini masih belum maksimal, sesuai dengan tujuan pembelajaran yang diharapkan sehingga guru harus melakukan perbaikan ulang. Dari data evaluai / tes ditemukan nilai rata-rata kelas 65,77 dan dari 
39 siswa terdapat 23 siswa $(58,97 \%)$ sudah mencapai nilai ketuntasan yaitu $\geq 70$, sedangkan sisanya $16(41,03 \%)$ siswa dari 39 siswa masih memperoleh nilai dibawah 70. Karena jumlah siswa yang memperoleh nilai 70 ke atas kurang dari $80 \%$, maka perlu dilanjutkan perbaikan pembelajaran pada siklus II.

Setelah diadakan proses pembelajaran pada sikus II dengan menerapkan model pembelajaran PBL (Problem Based Learning) seperti pada siklus I, terdapat peningkatan yaitu motivasi belajar siswa semakin meningkat dengan ditandai dengan antusiasnya siswa dalam mengikuti pembelajaran. Dan dipertemuan berikutnya diadakan penilaian secara individu dalam bentuk tes tertulis. Pada kegiatan ini ditemukan bahwa prestasi belajar dalam kegiatan siklus ini sudah maksimal, dan sesuai dengan tujuan belajar yang diharapkan. Dari data evaluasi / tes ditemukan nilai rata-rata kelas 72,46 dan dari 39 siswa terdapat 30 siswa $(76,92 \%)$ sudah mencapai nilai ketuntasan $\geq 70$, sedangkan 9 siswa $(23,08 \%)$ dari seluruh siswa berjumlah 39 siswa masih memperoleh nilai dibawah 70 . Karena jumlah siswa yang memperoleh nilai 70 ke atas kurang dari $80 \%$, maka perlu dilanjutkan perbaikan pembelajaran pada siklus III.

Setelah diadakan proses pembelajaran pada sikus III dengan menerapkan model pembelajaran PBL (Problem Based Learning) seperti pada siklus I dan siklus II, terdapat peningkatan yaitu motivasi belajar siswa semakin meningkat dengan ditandai dengan antusiasnya siswa dalam mengikuti pembelajaran. Dan dipertemuan berikutnya diadakan penilaian secara individu dalam bentuk tes tertulis. Pada kegiatan ini ditemukan bahwa prestasi belajar dalam kegiatan siklus ini sudah maksimal, dan sesuai dengan tujuan belajar yang diharapkan. Dari data evaluasi / tes ditemukan nilai rata-rata kelas 78,90 dan dari 39 siswa terdapat 34 siswa $(87,18 \%)$ sudah mencapai nilai ketuntasan $\geq 70$, sedangkan 5 siswa $(12,82 \%)$ dari seluruh siswa berjumlah 39 siswa masih memperoleh nilai dibawah 70. Karena jumlah siswa yang memperoleh nilai 70 ke atas lebih dari $80 \%$, maka tidak perlu dilanjutkan perbaikan pembelajaran siklus IV. Dari tiga siklus yang dilakukan dalam penelitian ini terdapat perkembangan yang membaik, terbukti dari prolehan nilai tiap-tiap siklus, mulai dari pra siklus-siklus I-siklus II-Siklus III terdapat kenaikan yang signifikan dan meningkat ditandai dengan nilai rata-rata kelas yang semakin meningkat, seperti yang disajikan pada tabel 1 dan gambar 2 berikut:

Tabel 1. Nilai Rata-Rata Instalasi Penerangan Listrik pada pra siklus, siklus I, siklus II dan siklus III

\begin{tabular}{clc}
\hline No & Siklus & $\begin{array}{c}\text { Nilai } \\
\text { Rata-Rata }\end{array}$ \\
\hline 1 & Pra Siklus & 56,24 \\
2 & Siklus I & 65,77 \\
3 & Siklus II & 72,46 \\
4 & Siklus III & 78,90 \\
\hline
\end{tabular}




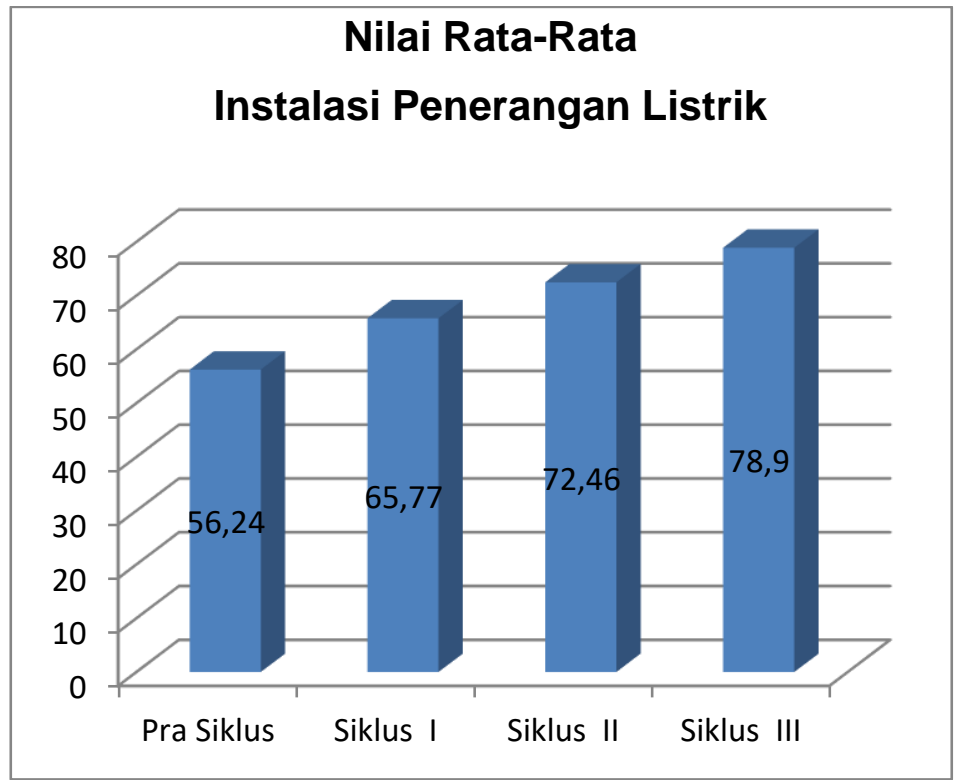

Gambar 2. Grafik Nilai Instalasi Penerangan Listrik pada prasiklus, siklus I, Siklus II dan siklus III

Penilaian kualitas proses pembelajaran juga mencakup penilaian kinerja siswa dalam pembelajaran instalasi penerangan listrik yang difokuskan pada (1) keaktifan siswa, (2) perhatian dan konsentrasi siswa, (3) minat dan motivasi siswa, dan (4) keterlibatan siswa dalam pembelajaran. Hasil yang didapatkan bahwa kinerja siswa mengalami peningkatan selama proses pembelajaran menggunakan model pembelajaran PBL seperti pada tabel 2 dan gambar 3 berikut:

Tabel 2. Ketuntasan Pembelajaran Instalasi Penerangan Listrik pada pra siklus, siklus I, siklus II dan siklus III

\begin{tabular}{clcc}
\hline \multirow{2}{*}{ No } & \multirow{2}{*}{ Siklus } & \multicolumn{2}{c}{ Ketuntasan } \\
\cline { 2 - 4 } & & Tuntas (\%) & Belum Tuntas (\%) \\
\hline 1 & Pra Siklus & $15,38 \%$ & $84,62 \%$ \\
2 & Siklus I & $58,97 \%$ & $41,03 \%$ \\
3 & Siklus II & $76,92 \%$ & $23,08 \%$ \\
4 & Siklus III & $87,18 \%$ & $12,82 \%$ \\
\hline
\end{tabular}




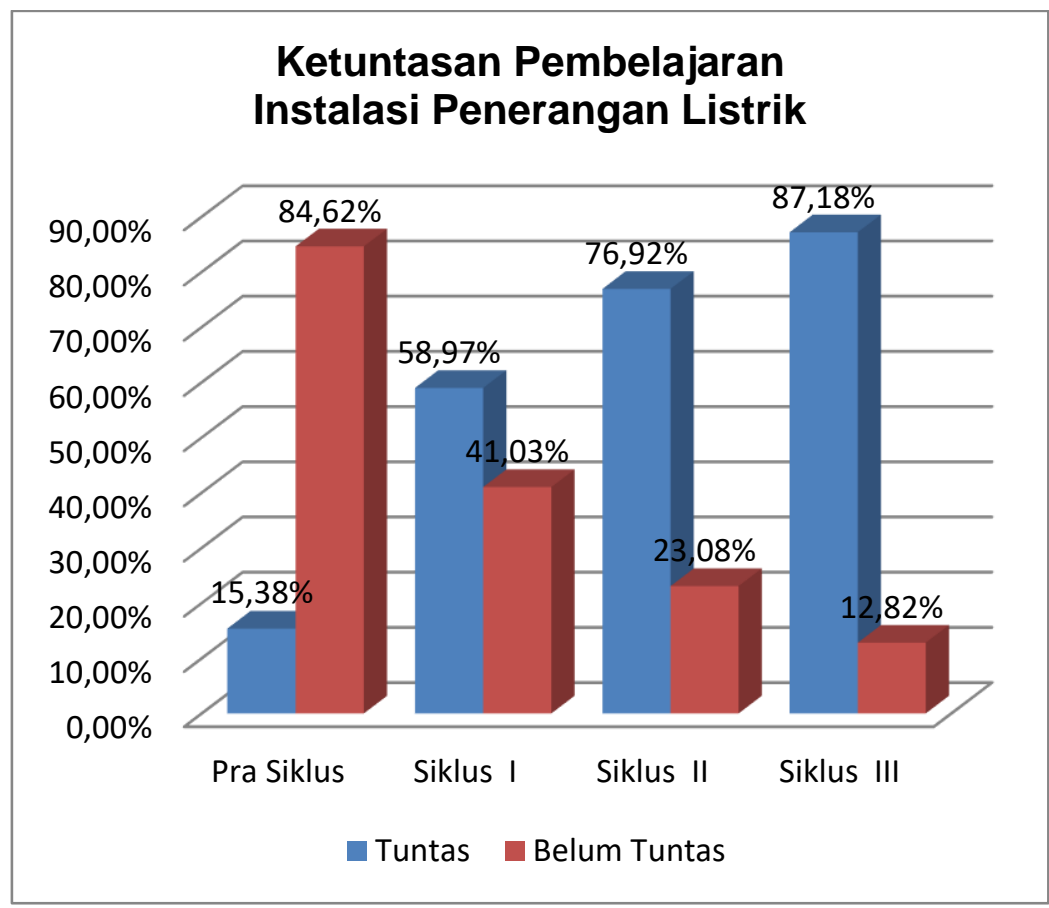

\section{Gambar 3. Grafik Ketuntasan Pembelajaran Instalasi Penerangan Listrik}

Problem Based Learning (PBL) atau pendekatan pembelajaran berdasar masalah, adalah pengajaran yang dirancang berdasarkan masalah riil kehidupan yang bersifat tidak tentu, terbuka, dan mendua. Masalah yang tidak tentu adalah masalah yang kabur, tidak jelas, atau belum terdefinisikan. Belajar berdasarkan masalah dapat membangkitkan minat siswa, nyata, dan sesuai untuk mengembangkan kemampuan berfikir serta memberikan kesempatan agar siswa belajar dalam situasi kehidupan nyata.

Problem Based Learning (PBL) dalam bahasa Indonesia disebut Pembelajaran Berbasis Masalah (PBM) merupakan penggunaan berbagai macam kecerdasan yang diperlukan untuk melakukan konfrontasi terhadap tantangan dunia nyata, kemampuan untuk menghadapi segala sesuatu yang baru dan kompleksitas yang ada.

Model Problem Based Learning (PBL) dikembangkan berdasarkan konsep-konsep yang dicetuskan oleh Jerome Bruner. Konsep tersebut adalah belajar penemuan atau discovery learning. Konsep tersebut memberikan dukungan teoritis terhadap pengembangan model PBL yang berorientasi pada kecakapan memproses informasi.

Menurut Barbara J. Duch (1996), Problem Based Learning (PBL) adalah satu model pembelajaran yang ditandai dengan penggunaan masalah pada dunia nyata untuk melatih siswa berfikir kritis dan terampil memecahkan masalah, dan memperoleh pengetahuan tentang konsep yang penting dari apa yang dipelajari (Wijayanto, 2009:15). Suyatno (2009) mengatakan Problem Based Learning (PBL) merupakan suatu model pembelajaran yang berbasis pada masalah, dimana masalah tersebut digunakan sebagai stimulus yang mendorong mahasiswa menggunakan pengetahuannya untuk merumuskan sebuah hipotesis, pencarian informasi relevan yang bersifat student-centered melalui diskusi dalam sebuah kelompok kecil untuk mendapatkan solusi dari masalah yang diberikan.

Sedangkan menurut Arend, Problem Based Learning (PBL) merupakan suatu model pembelajaran dimana siswa dihadapkan pada masalah autentik (nyata) sehingga diharapkan mereka dapat menyusun pengetahuannya sendiri, menumbuh kembangkan keterampilan tingkat tinggi dan inkuiri, memandirikan siswa, dan meningkatkan kepercayaan dirinya (Trianto, 2007). Pendapat yang sama disampaikan oleh Sanjaya (2006: 214), Problem Based Learning (PBL) 


\section{VOCATIONAL : Jurnal Inovasi Pendidikan Kejuruan Vol 1. No. 3, Juli 2021 P-ISSN : 2775-0019, e-ISSN : 2774-6283}

merupakan rangkaian aktivitas pembelajaran yang menekankan kepada proses penyelesaian masalah yang dihadapi secara ilmiah. Hakekat permasalahan yang diangkat dalam Problem Based Learning adalah gap atau kesenjangan antara situasi nyata dengan situasi yang diharapkan, atau antara yang terjadi dengan harapan.

Karakteristik Model Pembelajaran PBL (Problem Based Learning) menurut Trianto (2009:93) adalah: (1) adanya pengajuan pertanyaan atau masalah, (2) berfokus pada keterkaitan antar disiplin, (3) penyelidikan autentik, (4) menghasilkan produk atau karya dan mempresentasikannya, dan (5) kerja sama. Sedangkan menurut Rusman (2010:232), karakteristik model pembelajaran Problem Based Learning (PBL) adalah : (1) Permasalahan menjadi starting point dalam belajar dan permasalahan yang diangkat adalah permasalahan yang ada di dunia nyata yang tidak terstruktur, (2) Permasalahan membutuhkan perspektif ganda (multiple perspective) dan menantang pengetahuan yang dimiliki oleh siswa, sikap, dan kompetensi yang kemudian membutuhkan identifikasi kebutuhan belajar dan bidang baru dalam belajar, (3) Belajar pengarahan diri menjadi hal yang utama, dan pemanfaatan sumber pengetahuan yang beragam, penggunaannya, dan evaluasi sumber informasi merupakan proses yang esensial dalam problem based learning, (4) Belajar adalah kolaboratif, komunikasi, kooperatif dan proses belajarnya secara sintesis dan integratis (5) Pengembangan keterampilan inquiry dan pemecahan masalah sama pentingnya dengan penguasaan isi pengetahuan untuk mencari solusi dari sebuah permasalahan, dan (6) Problem based learning melibatkan evaluasi dan review pengalaman siswa dan proses belajar.

Tujuan yang ingin dicapai oleh PBL adalah kemampuan siswa untuk berpikir kreatif, analitis, sistematis, dan logis untuk menemukan alternatif pemecahan masalah malalui eksplorasi data secara empiris dalam rangka menumbuhkan sikap ilmiah yaitu : (1) Mengembangkan keterampilan berpikir dan keterampilan memecahkan masalah, (2) Belajar peran orang dewasa, dan (3) keterampilan-keterampilan untuk belajar mandiri.

Langkah-langkah operasional dalam proses pembelajaran yang dikonsepkan oleh Kementrian Pendidikan dan Kebudayaan adalah : (1) Konsep Dasar (Basic Concept), (2) Pendefinisian Masalah (Defining The Problem), (3) Pembelajaran Mandiri (Self Learning), (4) Pertukaran Pengetahuan (Exchange Knowledge), dan (5) Penilaian (Assessment)

Keunggulan penerapan model pembelajaran Problem Based Learning (PBL), yaitu (Sanjaya, 2006:220) : (1) Pemecahan masalah merupakan teknik yang cukup bagus untuk lebih memahami isi pelajaran sehingga pembelajaran lebih bermakna, (2) Pemecahan masalah dapat menantang kemampuan siswa serta memberikan kepuasan untuk menemukan pengetahuan baru bagi siswa, (3) Pemecahan masalah dapat meningkatkan aktivitas pembelajaran siswa, (4) Pemecahan masalah dapat membantu siswa bagaimana mentransfer pengetahuan siswa untuk memahami masalah dalam kehidupan nyata, (5) Pemecahan masalah dapat membantu siswa untuk mengembangkan pengetahuan barunya dan bertanggungjawab dalam pembelajaran yang dilakukan. Disamping itu, pemecahan masalah itu juga dapat mendorong untuk melakukan evaluasi sendiri baik terhadap hasil maupun proses belajarnya, (6) Melalui pemecahan masalah bisa memperlihatkan kepada siswa bahwa setiap mata pelajaran pada dasarnya merupakan cara berpikir, dan sesuatu yang harus dimengerti oleh siswa, bukan hanya sekedar belajar dari guru atau dari buku saja, (7) Pemecahan masalah dianggap lebih menyenangkan dan disukai siswa, (8) Pemecahan masalah dapat mengembangkan kemampuan siswa untuk berpikir kritis dan menyesuaikan dengan pengetahuan baru, (9) Pemecahan masalah dapat memberikan kesempatan siswa untuk menerapkan pengetahuan yang dimiliki dalam dunia nyata, dan (10) Pemecahan masalah dapat mengembangkan minat siswa untuk secara terus menerus belajar, sekalipun belajar pada pendidikan formal telah berakhir.

Kelemahan-kelemanan dari penggunaan model pembelajaran Problem Based Learning (PBL), adalah (Sanjaya, 2006:221) : (1) Manakala siswa tidak memiliki minat atau siswa 
berasumsi bahwa masalah yang dipelajari sulit untuk dipecahkan, maka akan merasa enggan untuk mencoba, (2) Keberhasilan model pembelajaran melalui Problem Based Learning membutuhkan cukup waktu untuk persiapan dan (3) Tanpa pemahaman mengapa siswa berusaha memecahkan masalah yang dipelajari, maka siswa tidak akan belajar apa yang ingin dipelajari.

Motivasi didefenisikan sebagai kondisi internal yang membangkitkan kita untuk bertindak, mendorong kita mencapai tujuan tertentu, dan membuat kita tetap tertarik dalam kegiatan tertentu. Motivasi adalah salah satu faktor yang mempengaruhi keefektifan kegiatan belajar siswa. Menurut Sardiman (2010) motivasi adalah perubahan energi dalam diri seseorang yang ditandai dengan munculnya "feeling" dan didahului dengan tanggapan terhadap adanya tujuan.

Prestasi belajar adalah kemampuan yang diperoleh siswa setelah melakukan kegiatan belajar mengajar matematika pokok bahasan bilangan riil yang diperoleh dari tes/evaluasi diakhir Siklus. Kegiatan belajar itu sendiri merupakan proses perubahan tingkah laku yang relatif menetap (Susanto, 2013). Prestasi belajar adalah kemampuan yang diperoleh anak setelah melalui proses kegiatan belajar (Hamim Tohari, 2019: 3). Prestasi belajar akan tercapai bila motivasi pada diri siswa tinggi. Siswa mungkin dapat dipaksa untuk menghayati perbuatan itu sebagaimana mestinya. Guru dapat memaksakan bahan pelajaran kepada siswa, tetapi tak mungkin memaksanya untuk belajar dalam arti sebenarnya. Oleh karena itu, guru harus berupaya agar siswa mau belajar dan memiliki keinginan belajar terus menerus.

Prestasi belajar adalah hasil atau akibat dari kegiatan belajar. Untuk mengetahui tentang presjtasi belajar perlu dijelaskan tentang hakekat belajar. Belajar merupakan suatu proses yang dilakukan seseorang untuk memperoleh suatu perubahan tingkah laku yang baru secara keseluruhan, sebagai hasil pengalaman (Slameto, 1991). Dimana perubahan itu bersifat kontinu dan fungsional, terjadi secara sadar, bersifat positif dan aktif bukan bersifat sementara, bertujuan atau terarah, dan mencakup seluruh aspek tingkah laku yang selanjutnya dinamakan hasil belajar. Dan hasil belajar tersebut dapat dinyatakan dalam bentuk prestasi belajar.

Menurut Abu Ahmadi (2004), belajar adalah suatu proses usaha yang dilakukan individu untuk memperoleh suatu perubahan tingkah laku yang baru secara keseluruhan sebagai hasil pengalaman individu itu sendiri dalam interaksinya dengan lingkungan. Berdasarkan pengertian belajar di atas, maka dapat didefinisikan tentang prestasi belajar, yaitu tingkat keberhasilan yang dicapai siswa berupa ketrampilan dan pengetahuan berdasarkan hasil tes atau evaluasi setelah pelaksanaan proses belajar mengajar. Sedangkan ketuntasan belajar merupakan hasil belajar siswa yang memenuhi kriteria standart tertentu. Seorang siswa dikatakan tuntas belajar bila mencapai ketuntasan indikator hasil belajar $\geq 70 \%$, dan suatu kelas dikatakan tuntas belajar bila dalam kelas telah mencapai $\geq 80 \%$ siswa yang telah tuntas belajar.

\section{KESIMPULAN}

Berdasarkan hasil penelitian dapat disimpulkan bahwa penggunaan model pembelajaran dengan menggunakan Problem Based Learning (PBL) dapat meningkatkan motivasi dan prestasi belajar Instalasi Penerangan Listrik pada siswa kelas XI Listrik SMK Negeri 1 Bangil Kabupaten Pasuruan Tahun Pelajaran 2018/2019. Hal ini dapat dibuktikan dengan meningkatnya hasil prestasi belajar yang diperoleh mulai dari pra siklus, siklus I, siklus II dan siklus III. Berdasarkan hasil penelitian, maka saran-saran yang disampaikan adalah untuk meningkatkan motivasi dan prestasi belajar siswa dapat menggunakan model pembelajaran Problem Based Learning (PBL) pada pelajaran Instalasi Penerangan Listrik maupun pelajaran lainnya. 


\section{DAFTAR PUSTAKA}

Ahmadi, A., dan Supriyono, W. (2004). Psikologi Belajar. Jakarta: Rineka Cipta.

Angko, N. (2013). Pengembangan Bahan Ajar dengan Model ADDIE untuk Mata Pelajaran Matematika Kelas 5 SDS Mawar Sharon Surabaya. Kwangsan, Jurnal Teknologi Pendidikan. Vol. 1, No. 1, DOI: https://doi.org/10.31800/jtp.kw.v1n1.p1-15

Arikunto, S., dkk. (2007). Penelitian Tindakan Kelas. Jakarta: Bumi Aksara.

Mukhlis, A. (ed). (2000). Penelitian Tindakan Kelas, Makalah Panitia Penulisan Karya Ilmiah untuk Guru-guru se-Kabupaten Tuban.

Nur, Muhammad. (1999). Pemotivasi Siswa Untuk Belajar. Surabaya: Unipress

Sanjaya, W. (2006). Strategi Pembelajaran. Jakarta: Kencana Prenada Media Group.

Sardiman. (2010). Interaksi dan Motivasi Belajar Mengajar. Jakarta : Bumi Aksara.

Slameto. (1995). Belajar dan faktor-faktor yang mempengaruhinya. Jakarta : Rineka Cipta

Susanto, A. (2013). Teori Belajar \& Pembelajaran di Sekolah Dasar, Jakarta : Kencana Prenada Media

Suyatno. (2009). Menjelajah Pembelajaran Inofatif. Sidoarjo: Masmedia Buana Pusaka.

Tohari, H. dkk. (2019). Pengaruh Penggunaan Youtube Terhadap Motivasi Belajar dan Hasil Belajar Mahasiswa. Kwangsan, Jurnal Teknologi Pendidikan. Vol. 07. No. 01. DOI: https://doi.org/10.31800/itp.kw.v7n1.p1-13

Trianto. (2007). Model-model Pembelajaran Inovatif Berorientasi Konstruktivistik. Jakarta: Prestasi Pustaka.

Trianto. (2009). Mendesain Model Pembelajaran Inofatif-Progresif. Surabaya: Kencana Prenada Media Group.

Wijayanto, M. (2009). Tesis: Pengaruh Penerapan Model Problem Based Learning dan Cooperative Learning terhadap Prestasi Belajar Matematika Ditinjau dari Motivasi Belajar Siswa (Studi Eksperimen pada Siswa Kelas X Sekolah Menengah Atas Negeri Kabupaten Wonogiri Tahun Pelajaran 2008/2009. Surakarta: UNS. 